\title{
INTERACTIONS AND ENERGY TRANSFER
}

\author{
Einar Uggerud ${ }^{*}$ \\ Department of Chemistry \\ University of Oslo \\ P. O. Box 1033 Blindern \\ $\mathrm{N}-0315$ Oslo
}

NORWAY

I have been lucky growing up and living in a safe and privileged part of the world, where I have benefitted from a historical high point in education, technology, economy, social structure and human freedom. I have also been lucky by meeting and relating to many interesting and gifted people, both in my private and professional life. This short memoir will describe some great moments in my academic life, and the lesson I want to teach the reader is how essential it is for a young researcher to be inspired by mentors and peers abroad and to visit their labs. Science can only exist and develop in this social context. Here, I will describe some individuals that have been important to my personal and scientific development. Unintentionally, I may have forgotten names that should also have been included but I have deliberately omitted everybody from my inner circle (own family and students) — bless them all.

My maternal grandfather, Kristen, was a teacher who was imprisoned for his opposition to Nazification during the German occupation of Norway. His heroic example vaccinated me against people who tell me to follow their desk plan for brave new world. Kristen loved meeting people, and this must have smitten over to me through DNA or by human influence. My maternal grandmother, Hjørdis, was also a teacher. She was a caring grandmother but behind her kind presence there was a strong will. When she was young and wanted to attend teaching seminar just a few years after Norwegian women got the right to vote, her father became furious and did not want to lend her the necessary money. His eldest daughter should get married, not go to school. Against this formidable opposition, she was still able to get her way and her education. That still impresses me.

\footnotetext{
${ }^{*}$ Correspondence to: Einar Uggerud, Department of Chemistry, University of Oslo, P. O. Box 1033 Blindern, N0315 Oslo, Norway. E-mail: einar.uggerud@kjemi.uio.no
} 
My paternal grandfather, Einar, was an engineer, without formal education beyond elementary school and one year in a polytechnic. He was a technically skilled man, with a passion for order and practical purpose. He kept mercury and magnets in the bottom drawer in the kitchen. At the age of five I was allowed play with these gems. This was an influential experience and must have triggered my curiosity for matter and natural phenomena. My paternal grandmother, Ruth, was intelligent but neurotic.

My parents, Roar and Anna, both went to university. Roar ended up as a surgeon and Anna became a pharmacist. I know they both expected their eldest son to follow a similar educational path, and the reader will understand that I never made an opposition to that idea. Due to post-war rules for bringing health services to the whole population, my father could not find a permanent position in a hospital until I was 15 years old, so we moved frequently during my childhood. My parents were busy, each with their own life, having limited time and ability to express love to their children, but they gave us a lot of freedom. I was a happy but restless young boy, always with a good ability to find exciting things to do. Throughout my childhood I made friends from all over the country and it made no difference whether my friend's father was a big business manager or a working man. This social manifold was the result of a school system being public in its actual meaning (not the British) — a highly appreciated quality of my country. Being the oldest of four, it became natural for me to take responsibility already from an early age.

High school (Kongsvinger gymnas) was an adventure, an academy in its own right. Whether the teacher was a drunkard, an intellectual powerhouse and light tower, a good teller of stories, a pedant or a semi-psychopath-I learned something new every day. When the teacher was a didactic genius, I skipped reading the book. When the teacher was unable to explain even the simplest things, I had to read the book. Both methods work, it turned out.

At university I enjoyed maths, but chemistry and physics were more challenging and had more levels and edges. For a long time, I could not decide between the two. Mercury or magnets? I ended up with chemistry, the only topic from high school I did not understand much about. For my master's degree in organic chemistry my supervisor was Georg Hvistendahl. Georg was the kindest of all men, having recently spent a year in Cambridge picking up the hottest news in mass spectrometry. He presented me with the book "Metastable Ions" by Beynon, Caprioli, Cooks, and Fontaine and a couple of papers he had written and 
asked me to explain why $\mathrm{H}_{2}$ eliminations from some small energized molecule ions give rise to exceptionally high translational releases. The prototype reaction was dehydrogenation of protonated formaldehyde,

$$
\mathrm{H}_{2} \mathrm{COH}^{+} \rightarrow \mathrm{HCO}^{+}+\mathrm{H}_{2}
$$

The measurements were done by means of our AEI MS902 mass spectrometer equipped with a Digital Equipment PDP-8/E computer. I synthesized the precursor ion with all possible combinations and permutations of $\mathrm{H}$ and $\mathrm{D}$ atoms and measured both translational energy release, energetics and kinetics. Since around $80 \%$ of the liberated energy ended up as relative translational energy of the two fragments, Eq. 1 can simply be characterized as a gigantic molecular explosion. It was fascinating to observe that the exact amount of translational energy varied some with the isotope substitution pattern-but both the $80 \%$ fraction and the isotope effects were extremely difficult to interpret. It took me more than ten years to understand it all and thereby complete the task Georg had given me-long after I had finished my master and $\mathrm{PhD}$ degrees, vide infra. In any instance, I learned a lot during this period - from organic synthesis to machine code programming.

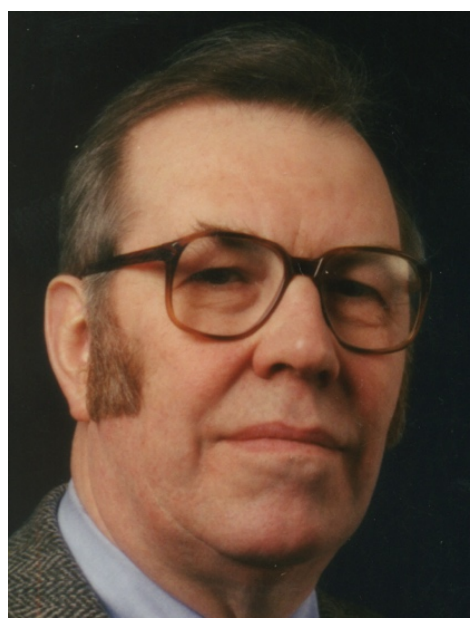

Figure 1. Georg Hvistendahl. Private photo. 


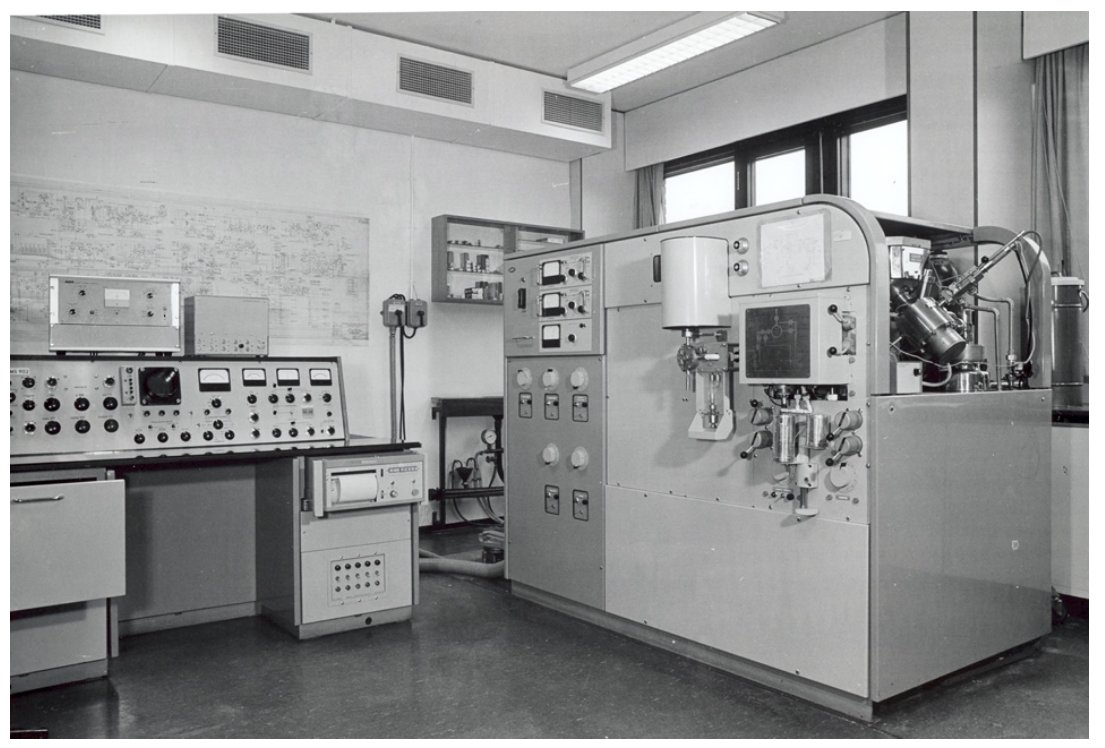

Figure 2. The MS 902 in our lab. Private photo.

Both Georg and I enjoyed our long afternoon conversations around the physics and chemistry of my thesis work and a thousand other topics. This was exactly how life in the ivory tower should be. Our discussions shaped my critical sense about accuracy, counting statistics, ion optics and instrument effects. Because Georg had few academic ambitions of his own, my manuscripts spent a long time on his desk and few papers came out. The wake-up call was given by one of my teaching-assistant colleagues, "Einar, to stay alive in academia is brutalpublish or perish". This helped me. I also got a push in the same direction by Jan Almlöf of our department. Jan introduced me to the forefront of international quantum chemistry, where he was a central figure himself. I took great advantage of his knowledge and guidance.

After completing my Ph.D. in 1984, I went to Berlin to work with Helmut Schwarz. Helmut was the counterpoint to Georg; energetic, ambitious, efficient; and with a fascinating good memory of everything he had read. I was permanently influenced by the way he was able to link mass spectrometric experiments to chemistry in general, and to chemical reactivity and reaction mechanisms in particular. I was fascinated by the high quality of chemistry teaching in the German universities, but I found their system very authoritarian - a challenge to a young man who had spent his formative years as a free scientific soul with a very liberal supervisor. The international atmosphere in Helmut's lab combined with the high technical and academic standard of his co-workers provided a new calibration point for my own work. I experienced long days and nights in the lab wrestling with the fantastic three-sector ZAB mass spectrometer and feeding the Cray supercomputer in Konrad-Zuse-Rechnenzentrum 
with quantum chemical calculations. I should not forget to tell that Helmut remains a good friend and supporter until this day.

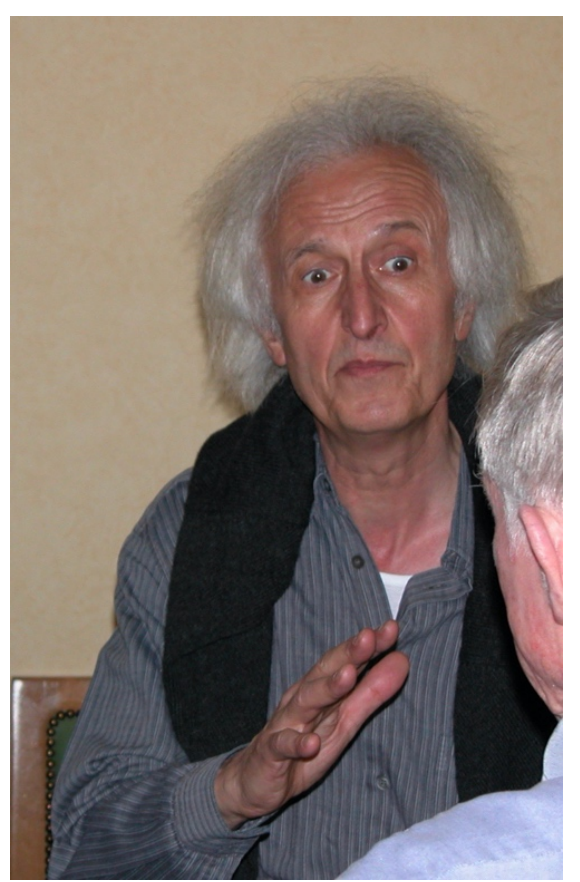

Figure 3. Helmut Schwarz. Private photo.

Returning home after half a year in Berlin in 1985, I had to decide whether I should follow the narrow academic path or find myself a steady job. The vote was in favour of the former alternative, and in the next years I was able to get funding for postdoctoral work from different external sources. I was the protégé of Lars Skatteb $\phi l$ (organic chemist par excellence with a named reaction) and Otto Bastiansen (co-author on Odd Hassel's seminal papers that gave Hassel the Nobel prize in chemistry). They helped touching the right buttons and I am forever grateful for their support.

Georg Hvistendahl had told me about a Danish colleague of reputation, Steen Hammerum. I have calculated that I met Steen for the first time in 1984 at the third Sandbjerg Symposium on Organic Mass Spectrometry, a legendary series of meetings he organized. The fourth and last Sandbjerg symposium was held in 1989. At Sandbjerg I met colleagues from many countries, making life-long connections and friendships that have been very valuable. 


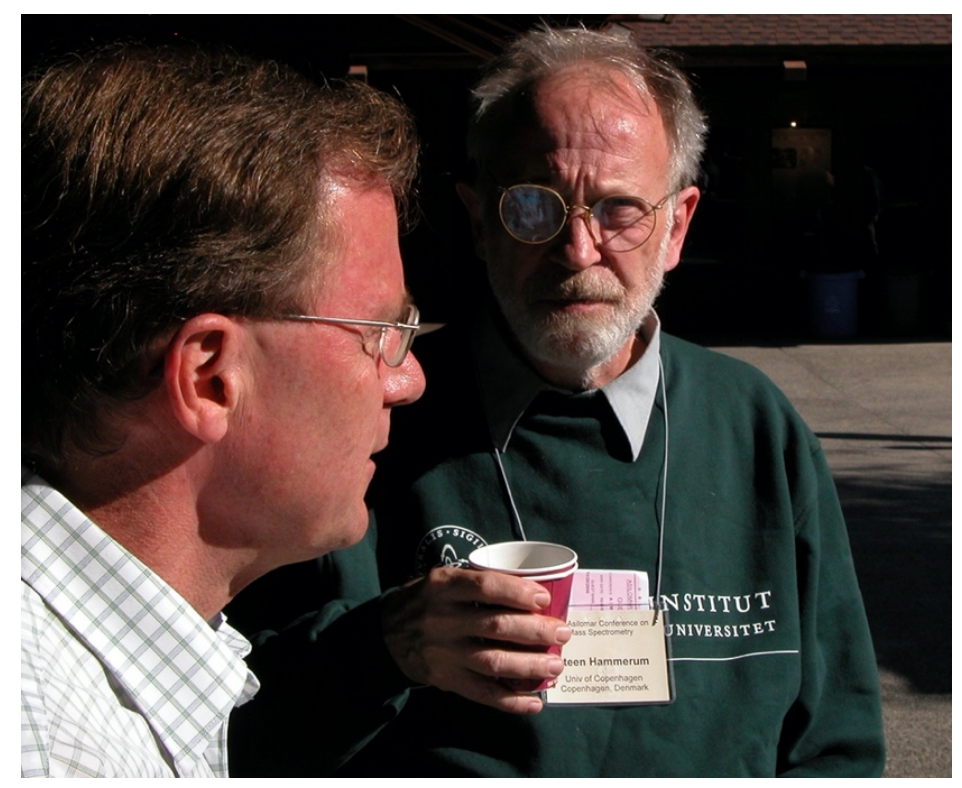

Figure 4. Dietmar Kuck and Steen Hammerum. Private photo.

Steen Hammerum is intellectually demanding in the way he deals with you if he considers you to be of his own league, challenging you with your linguistic and conceptual inaccuracies and lack of consistent thinking in the true Socratian tradition. To some people this was irritating, but I am grateful for his criticism, since it helped clearing my thinking and sharpening my pen. I must add that he is the most considerate, well prepared and engaged teacher and scientist one can think. The strangest thing is that although Steen and I have met so many times, worked together in the same laboratory for weeks, and have had deep nightly scientific and philosophical discussions until the whisky bottle was empty, we have not published a single paper together. The closest I have come in this respect is that I wrote a couple of papers with his student Tore Vulpius, who also became a friend.

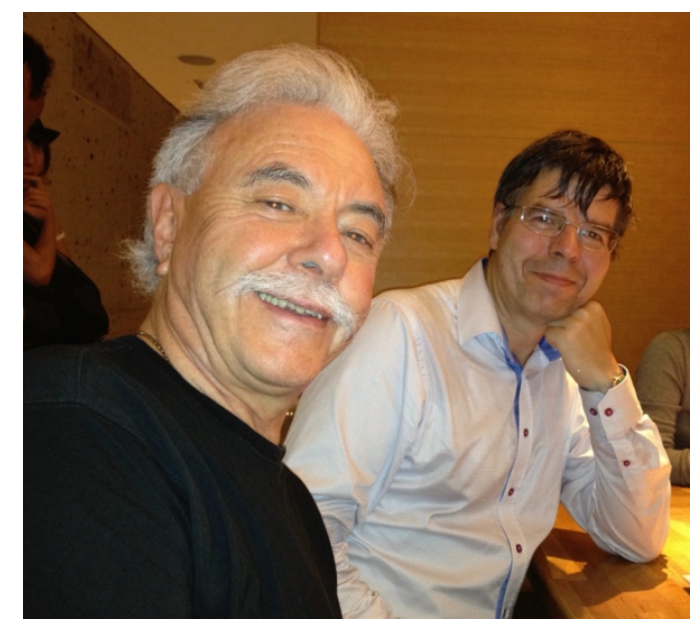

Figure 5. Peter J. Derrick and the author. Private photo. 
I met Peter Derrick at Sandbjerg. Steen had worked with Peter in Australia, and when Peter returned home to England in 1987 as Research professor in mass spectrometry at the University of Warwick, it became much easier to visit. It was straightforward to establish good contact with Peter due to his friendly and humoristic personality and because we shared the same scientific interests, in particular reaction dynamics of unimolecular reactions, translational energy release measurements and energy redistribution. Peter was an ion optics wizard, and I learned a lot from him and his co-workers about mass spectrometric instrumentation. He housed the MMM in his lab, a self-constructed grand-scale mass spectrometer. When I visited Warwick for four summer months in 1988, I was eager to work with this machine. Unfortunately, the MMM was not ready for use after the move from Australia, so I had to resume to other activities. Peter provided me with a couple of Ph.D. theses from his Australian students that were full of interesting experimental data and cried out for further analysis. As a result of this, Peter and I worked out a theory on impulsive energy transfer during collision activation, which got much attention in the community (Uggerud,1991).

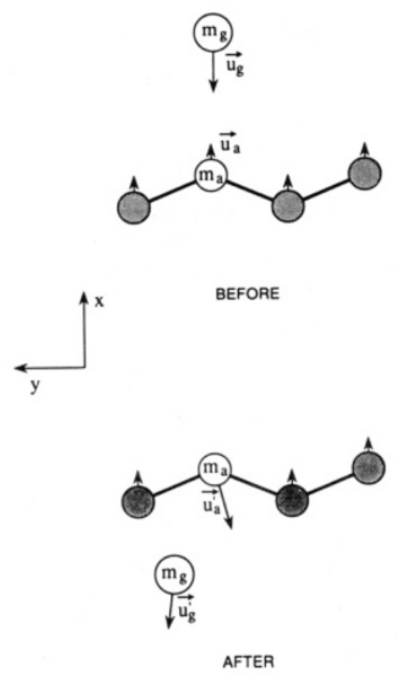

Figure 6. Schematic representation of a collision between an ion and a gas atom. Facsimile from our impulsive collision paper (Uggerud, Derrick,1991). Reproduced with permission from the copyright holder.

I knew Nico Nibbering's name from a tutorial he had written, "Isootop Effecte in Massaspectrometrie" when I was a student. I remember meeting him in Sandbjerg in 1989. This was the year of European optimism, and Nico was very enthusiastic about the idea of European unification and wanted to establish a European society for mass spectrometry. 
Later, he extended the plan and became the co-founder of the International Mass Spectrometry Foundation. When I visited him in Amsterdam, I was impressed by the people and the instrumentation in his lab-including an FT-ICR instrument they had built themselves - but even more about how he and his team were able to take advantage of the technology in bringing original ideas forward to new basic chemical knowledge. Nico stood up against administrative pressure for short time utility. Besides his stubbornness and enthusiasm, Nico cared about and loved people. He supported this young Norwegian in his first career steps and eventually invited me to become an editor of Mass Spectrometry Reviews not long before he retired from his editorship.

Steen Hammerum's Sandbjerg symposium was also the cradle for a European Union research project within the SCIENCE program (now the Horizon program). Most of the people mentioned above took part, including Hans-Friedrich Grützmacher and Dietmar Kuck, both of the University of Bielefeld. These pleasant and gifted gentlemen were both of North German origin with high affinity to salty water and the letters HSV - organic chemists by heart and mass spectrometrists by profession. The collaboration with Dietmar could easily have ended up as that with Steen, without common papers, but we were finally able to correct for this shortcoming many years later. Another great chemist within the SCIENCE team was Henri Eduard Audier. Reading his fine papers was always joyful and inspiring.

I was a senior research fellow of the The Norwegian Research Council, 1989 - 90, and so was Trygve Helgaker who had been Jan Almlöf's student. Trygve was based in Århus at that time and had success with implementing efficient and accurate methods in quantum chemical programs for calculating first and second energy derivatives with respect to nuclear displacements. When hearing about this achievement, I realized that it provided the fundament for modelling the dynamics of the dissociation processes I had studied experimentally as a master student and perhaps solve my riddle. I contacted Trygve and got his computer code together with the rest of the ABACUS/SIRIUS program system (later rebaptized to DALTON). My intention was to code the molecular dynamics method myself on the basis of the supported material but soon found out that this was more complicated than I had anticipated, not the least due to the sparse program documentation, to put it mildly. I therefore made the trip to Århus where Trygve and the other talented people of the Århus theoretical chemistry group could provide the sorely required expertise. After having tested out our method for trajectory calculations on-the-fly, we could for the first time compute 
translational energy release based on ab initio electronic structures. The calculations were able to reproduce experimental translational energy release and isotope effects of the hydrogen eliminations of Eq. 1 (Uggerud,1992). This was a very happy moment since the goal of my master thesis project had finally been realized (Uggerud,1999). Trygve is now a good colleague and friend here in Oslo, and we still occasionally publish together.

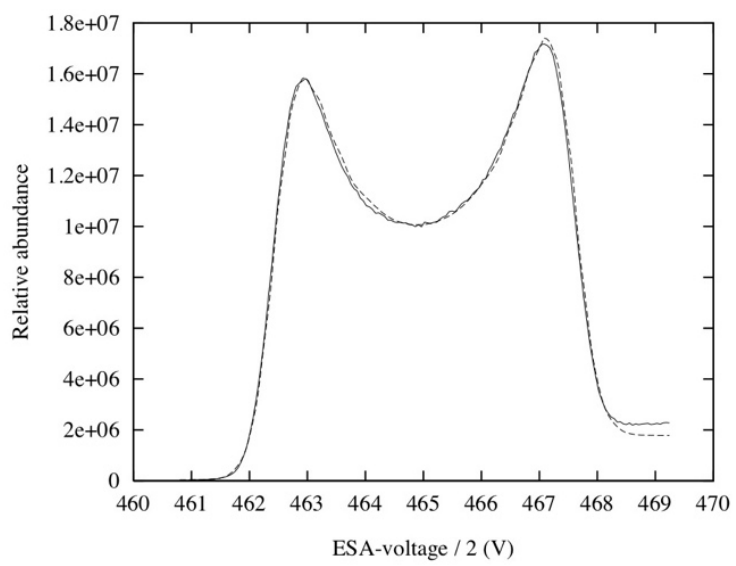

Figure 7. Signal for the metastable ion dissociation process $\mathrm{CH}_{2} \mathrm{NH}_{2}{ }^{+} \rightarrow \mathrm{HCNH}^{+}+\mathrm{H}_{2}$. The wide double maximum peak is characteristic for a process giving rise to a large translational energy release. The full line connects the experimental data points while the broken line is the best fit to a model used to obtain the translational energy release distribution by deconvoluting instrument factors. Reproduced from (Øiestad,1997) with permission from the copyright holder.

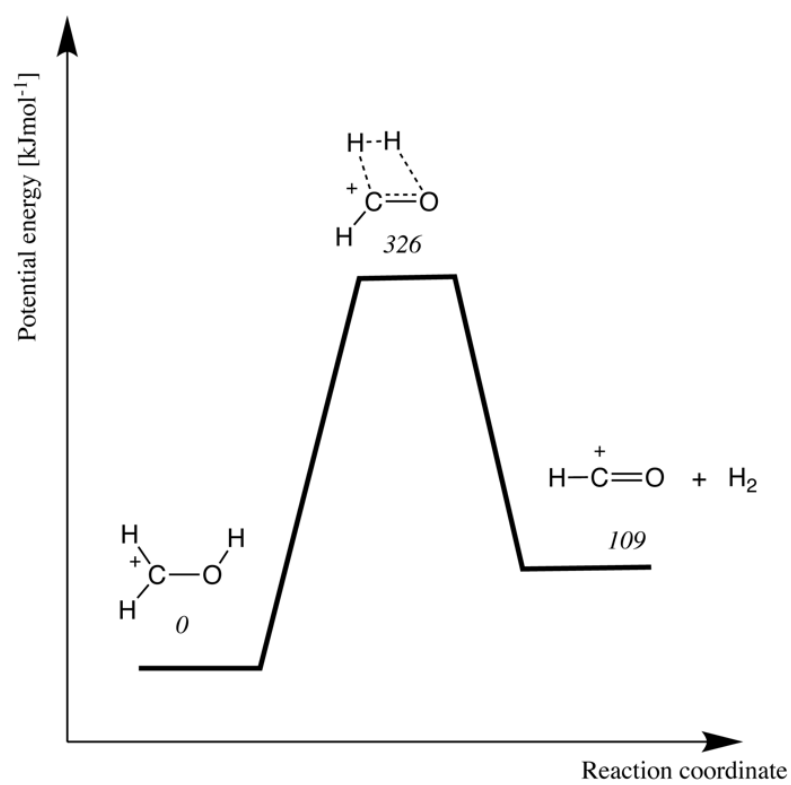

Figure 8. Energy diagram for the reaction $\mathrm{H}_{2} \mathrm{COH}^{+} \rightarrow \mathrm{HCO}^{+}+\mathrm{H}_{2}$ reconstructed from data taken from (Hvistendahl,1991). During the dissociation, $217 \mathrm{kJmol}^{-1}$ is liberated, most of it ending up as relative translation. 
Isotope effects on translational energy release

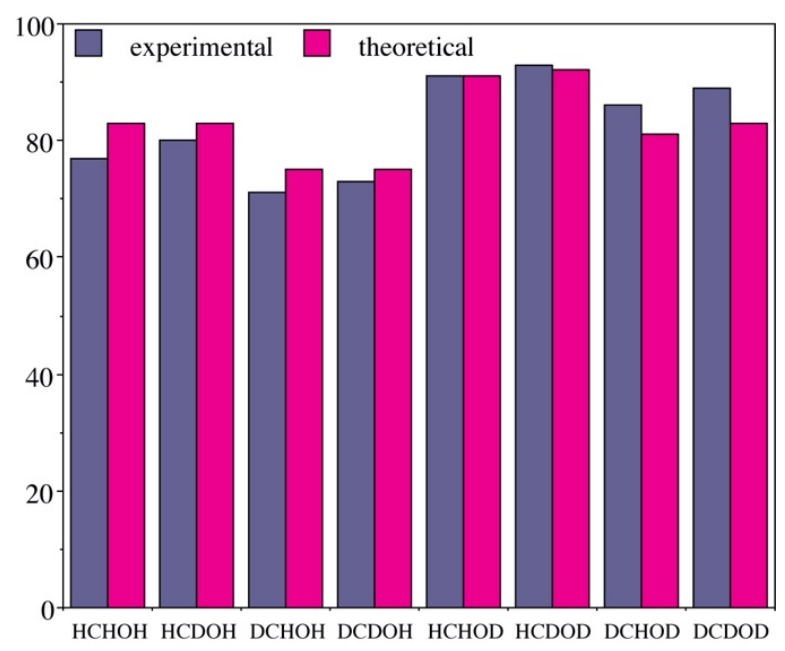

Figure 9. Relative proportion of the reverse critical energy liberated as relative translational energy of the two fragments formed for the reaction $\mathrm{CH}_{2} \mathrm{OH}^{+} \rightarrow \mathrm{CHO}^{+}+\mathrm{H}_{2}$ and its seven isotopomeric variants, as indicated. The blue columns represent the experimental data, while the red columns represent the results of on-the-fly dynamical calculations (Uggerud, Helgaker,1992). Reproduced with permission from the copyright holder.

My first practical experience with an FT-ICR mass spectrometer and ion-molecule reactions took place in 1989 at the University of Delaware when I visited Doug Ridge for the first time. Doug is a thoughtful and considerate man with a good sense of humour and is a first-rate physical chemist with whom I enjoyed working. We studied the energetics of dissociation reactions occurring upon proton transfer,

$$
\begin{aligned}
& \mathrm{AH}^{+}+\mathrm{M} \rightarrow \mathrm{MH}^{+}+\mathrm{A} \\
& \mathrm{MH}^{+} \rightarrow \mathrm{F}^{+}+\mathrm{N}
\end{aligned}
$$

In terms of equilibrium thermodynamics, the proton transfer step is associated with a certain energy release, the exothermicity of the reaction. When we monitored the formation of fragment ions by varying the protonation agent, $\mathrm{AH}^{+}$, we noticed that only a given fraction of the energy released, typically a half, ended up as internal energy in $\mathrm{MH}^{+}$. When we combined this information with information from experiments we obtained using the four-sector Jeol instrument in Copenhagen (named "Fred" by Steen Hammerum after Fred McLafferty - the grand old man of organic mass spectrometry) and quantum chemical calculations we were able to quantify this fraction (Lin,1994;Kinser,1996). This phenomenon continued to interest me in the following years, and further insights into energy fractionation during proton transfer 
events was later provided by on-the-fly trajectory calculations using the methodology we had developed in Århus (Bueker,1995;Bueker,1996). The head of department in Delaware was the one and only Jean Futrell. Jean had a mass spectrometer specially designed for studying angular resolved energy deposition during collisional activation. Jean was aware of the paper Peter and I had written on the subject, and we immediately found a common playing ground. I have had the privilege of keeping in contact with Jean since then. Besides his many scientific achievements, he has always been a strong promotor of his co-workers and young colleagues, including myself.

When I was a student, in the pre-internet period, students and professors at the Department of Chemistry met in the library every Monday and Thursday morning to read the newest journals and discuss what we had read. Very early I took particular notice of two names, Graham Cooks and Jack Beauchamp, who were both original and productive. Later I found out that the two of them had another thing in common, namely their ability to attract excellent coworkers and colleagues. Purdue university had the highest density of faculty members doing mass spectrometry in the world. Besides Graham, the staff included Ben Freiser, Bob Squires and Hilkka Kenttämaa. At Caltech, Jack fostered a string of notable mass spectrometrists: Doug Ridge, Ben Freiser, Tom Morton, Peter Armentrout and Terry McMahon. My list of other favourite ion chemists based in North American includes John Brauman, Diethard Bohme, Mike Bowers, František Tureček, Chuck DePuy, Veronica Bierbaum, Carl Lineberger, Will Castleman and Paul Kebarle. The list can be extended upon request.

The work of Kebarle and Castleman on equilibrium measurements of molecular clustering was particularly stimulating since it widened my scope of gas phase ion chemistry. In gas phase chemistry one traditionally studies the behaviour of isolated molecules, free from interaction with solvents or heat baths. This idealistic state of matter is interesting in its own right because one learns about the inherent properties of molecules, exactly as chemistry is described in textbooks. Nevertheless, chemical reactions normally take place in solution either inside a round bottomed flask or in a large industrial reactor, or within the complex environment of a living cell. It turns out that reactivity and other chemical properties are strongly affected by solvation. By successively adding one, two and more solvent molecules (S) to a central molecule or ion $(\mathrm{M})$, 


$$
\mathrm{M} \rightarrow \mathrm{MS} \rightarrow \mathrm{MS}_{2} \rightarrow \rightarrow \mathrm{MS}_{n} \rightarrow \rightarrow \mathrm{MS}_{\infty}
$$

it becomes possible to systematically study how chemical properties, including reactivity, gradually changes all the way from the isolated molecule (M) to the bulk solvated state $\left(\mathrm{MS}_{\infty}\right)$. Cluster chemistry has therefore always been a passion to me. We started the construction of a high-pressure drift cell source in Oslo in the late 1980's, and got indispensable help from John Stone, a pioneer in gas phase cluster chemistry and ion mobility mass spectrometry. I remember that during one of my US trips, it must have been in 1990, I wanted to visit another well-reputed cluster chemist, namely Michael Meot-Ner who was affiliated with NIST in Gaithersburg, MA. Unfortunately, when I showed up in his lab, he was not there. I was told that he rarely was on site but preferred to stay safe in New Zealand. Instead, I was lucky to meet his associate, Wayne Zieck, a most colourful and experienced person, with whom I had a long informative conversation. Right there, I learned many of the tricks of high-pressure ion mass spectrometry that helped me setting up my own apparatus when I came home. By the way, in mass spectrometry high pressure is 10 mbar.

In 1994, a dream came true when we were able to purchase the first FT-ICR instrument in the Nordic countries, a Bruker Apex 47. This had not been possible without the strong support of the head of our department, Knut Fagri, and his network of influential people. Knut was the colleague of Jan Almlöf and Trygve Helgaker and together they laid the foundation for what much later became a successful centre of excellence in theoretical and computational chemistry. With the FT-ICR in hand, we were able to pursue many interesting projects, of which I here will limit myself in describing only three.

After numerous attempts, we finally succeeded in producing protonated hydrogen peroxide in the gas phase inside the FT-ICR. Having achieved this, we were thrilled by observing that this elusive species is an extremely strong oxidant being able to activate $\mathrm{C}-\mathrm{H}$ bonds, a hot chemical topic then and now (Øiestad,2001). With the sole exception of methane, this species directly abstracts hydride from any hydrocarbon, e.g.

$$
\begin{aligned}
\mathrm{HOOH}_{2}^{+}+\mathrm{RCH}_{3} & \rightarrow \mathrm{RCH}_{2}^{+}+2 \mathrm{H}_{2} \mathrm{O} \\
& \rightarrow \text { alkene }+\mathrm{H}_{2} \mathrm{O}: \mathrm{H}_{3} \mathrm{O}^{+} \\
& \rightarrow \text { alkene }+\mathrm{H}_{2} \mathrm{O}+\mathrm{H}_{3} \mathrm{O}^{+}
\end{aligned}
$$


Again, on the basis of a series of on-the-fly trajectory calculations, we were able to provide a detailed model of the dynamics of the reactions and the product distribution.

In another study, we reacted isotopically labelled water with a series of protonated alcohols (Uggerud, Bache-Andreassen,1999), and found ourselves immediately around the pivoting point of classic physical organic chemistry, being able to study the competition between nucleophilic substitution and elimination in greatest possible detail:

$$
\begin{aligned}
\mathrm{H}_{2}{ }^{18} \mathrm{O}+\mathrm{ROH}_{2}{ }^{+} & \rightarrow \mathrm{R}^{18} \mathrm{OH}_{2}^{+}+\mathrm{H}_{2} \mathrm{O} \\
& \rightarrow \text { elimination products }
\end{aligned}
$$

The rather irregular reactivity trends we observed for the $S_{N} 2$ reaction when we varied the alcohol helped us to raise critical questions (in the spirit of Hammerum) of the use of illdefined terms like the steric effect, still lazily used in papers and textbooks of organic chemistry. The mechanisms of substitution reactions have continued to interest me until this day, and I think I now finally understand all factors that determine reactivity, both in the gas phase and in solution (Uggerud,2017).

Table 1. Reaction rate, $k$, for ${ }^{18} \mathrm{OH}_{2}+\mathrm{R}^{16} \mathrm{OH}_{2}{ }^{+} \rightarrow{ }^{16} \mathrm{OH}_{2}+\mathrm{R}^{18} \mathrm{OH}_{2}{ }^{+}$and critical energy (potential energy difference between transition state and reactants/products), $E_{\text {crit, }}$, for the identity $\mathrm{S}_{\mathrm{N}} 2$ reactions $\mathrm{OH}_{2}+\mathrm{ROH}_{2}{ }^{+} \rightarrow$ $\mathrm{OH}_{2}+\mathrm{ROH}_{2}{ }^{+}$. For an identity reaction, reactants and products have identical energies. For the actual experiments, ${ }^{18} \mathrm{OH}_{2}+\mathrm{R}^{16} \mathrm{OH}_{2}{ }^{+} \rightarrow{ }^{16} \mathrm{OH}_{2}+\mathrm{R}^{18} \mathrm{OH}_{2}{ }^{+}$however, due to slight differences in zero-point energies

\begin{tabular}{|c|c|c|}
\hline $\mathrm{R}=$ & $k\left[\mathrm{~cm}^{3} \text { molecule }{ }^{-1} \mathrm{~s}^{-1}\right]^{\mathrm{a}}$ & $E_{\text {crit }}\left[\mathrm{kJmol}^{-1}\right]^{\mathrm{b}}$ \\
\hline $\mathrm{CH}_{3}$ & $2.2 \cdot 10^{-13}$ & 3.3 \\
\hline $\mathrm{CH}_{2} \mathrm{CH}_{3}$ & $6.7 \cdot 10^{-14}$ & 8.4 \\
\hline $\mathrm{CH}_{3} \mathrm{CHCH}_{3}$ & $4.6 \cdot 10^{-11}$ & -10.7 \\
\hline$\left(\mathrm{CH}_{3}\right)_{3} \mathrm{C}$ & $4.0 \cdot 10^{-10}$ & -18.1 \\
\hline
\end{tabular}
reactants and products have almost identical energies.

a(Uggerud, Bache-Andreassen,1999), ${ }^{\text {b }}$ Laerdahl,2003) 

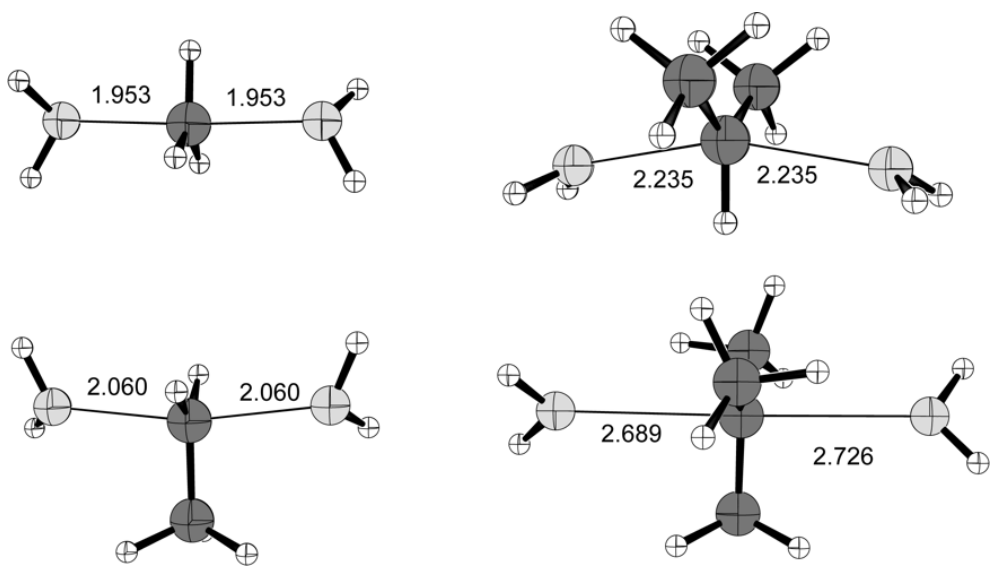

Figure 10. Transition state geometries for the identity $\mathrm{S}_{\mathrm{N}} 2$ reactions $\mathrm{OH}_{2}+\mathrm{ROH}_{2}{ }^{+} \rightarrow \mathrm{OH}_{2}+\mathrm{ROH}_{2}{ }^{+}$reproduced from (Laerdahl, Uggerud,2003) by permission from the copyright holder. Please notice the gradual change in the $\mathrm{C}-\mathrm{O}$ bond distances upon increasing methyl substitution. For $t$-Butyl (lower right) the transition state can hardly be distinguished from a hydrated t-Butyl cation. This and many other observations of gas phase, cluster and solvation chemistry provide a consistent overview of the $\mathrm{S}_{\mathrm{N}} 1 / \mathrm{S}_{\mathrm{N}} 2$ mechanistic landscape and the closely associated E1/E2 landscape as elucidated in (Uggerud,2017).

With the FT-ICR we purchased a cluster source designed and made in the group of Vladimir Bondybey in München. I then got to know two very clever young scientists, Martin Beyer and Gereon Niedner-Schatteburg, with whom I have had the pleasure of crossing paths with many times since. The cluster source served us well, and with inspiration taken from catalysis, we studied a number of metal clusters and probed their reactivity towards various compounds. One particularly illustrative example on $\mathrm{C}-\mathrm{H}$ activation was the reaction of size-selected platinum clusters towards hydrocarbons, leading to dehydrogenation. In the case of methane

$$
\mathrm{Pt}_{n}{ }^{+}+\mathrm{CH}_{4} \rightarrow \mathrm{Pt}_{n} \mathrm{CH}_{2}^{+}+\mathrm{H}_{2}
$$

it was fascinating to observe how reactivity varies significantly with the size of the cluster, where extremely poor reactivity was noted for $n=4,10$ and 15 (Adlhart,2006). These results indicate a direct relationship between the exact geometry, the electronic properties and the reactivity of small clusters. For a metal catalyst the active sites are known to be unevenly shaped small metal particles or local deformations (edges and kinks) of a metal surface. Modern catalysis research is aimed at better understanding these structure/reactivity relationships. 
One advantage of being a scientist is that it brings you around the globe. I became very eager when I got an invitation to tour Australia in 2001. My Australian colleagues all turned out to be great hosts - informal, down to earth and great scientists. In Sydney, Gary Willett, who had been Peter Derrick's student, involved me in a mutually beneficial and memorable discussions about all sides of cluster chemistry. He even included me in his family life by bringing me to a wedding in a hippie village in Blue Mountains and to the sheep farm of his brother-in-law in the bush. In Canberra I met with Leo Radom, a distinguished computational quantum chemist with whom I share a common interest in physical organic chemistry. In Melbourne I was warmly welcomed by Richard $O^{\prime} H a i r$, who has an unusual ability to use the mass spectrometer for probing the reaction mechanisms of industrial catalytic processes - great guy and great stuff. For many years, I had read exciting papers by John Bowie, Richards's mentor, and had looked much forward to visit also him. Unfortunately, he was unavailable at that time, so I had to skip Adelaide from my Australian tour.

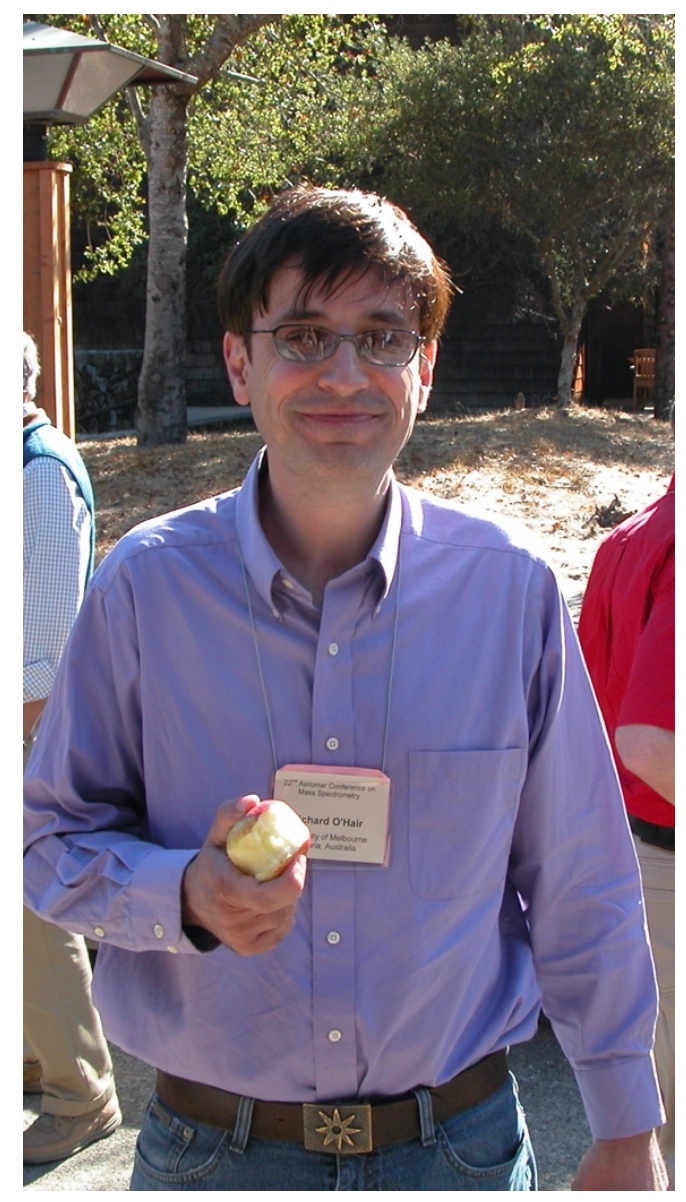

Figure 11. Richard O'Hair. Private photo.

I was able to conduct experiments at the ion storage ring facility CRYRING in Stockholm in 2002 thanks to the expertise of the technical staff and the other members of our great cross 
disciplinary team. The experiments had relevance to a then emerging topic in mass spectrometry, electron capture dissociation (ECD) - a technique for selectively fragmenting multiply protonated peptides and proteins - established by Roman Zubarev and Fred McLafferty. The process can be summarized in the following way, using a doubly charged molecule as example:

$$
\mathrm{M}^{2+}+\mathrm{e}^{-} \rightarrow\left(\mathrm{M}^{+}\right)^{*} \rightarrow \mathrm{F}^{+}+\mathrm{N}
$$

It was important to understand the mechanism of this two-step process - the electron capture event and the subsequent dissociation of the intermediate energy rich radical cation $\left(\mathrm{M}^{+}\right)^{*}$. It had been observed that the fragmentation pattern observed for ECD is very different from that observed upon collisionally induced dissociation, both in terms of which bonds that break and the energy redistribution before and during dissociation. Roman Zubarev, then in Uppsala, was a member of our team and so were two excellent molecular physicists from Stockholm university, Rich Thomas and Mats Larsson (with whom I have continued to collaborate until this day), and two excellent physical chemists from Göteborg, Jan Pettersson and Patrik Andersson. Besides studying the fragmentation of a small protonated peptide, we were able to investigate the fine details of ECD of the ammonium ion. One main reaction channel was observed to be dominant

$$
\mathrm{NH}_{4}{ }^{+}+\mathrm{e}^{-} \rightarrow \mathrm{NH}_{3}+\mathrm{H}^{-}
$$

We measured the translational energy released during this dissociation, which accounts for around $30 \%$ of the total energy deposited (Andersson,2010). Again, on-the-fly trajectory calculations provided the mechanistic details, and nicely reproduced the experiments. 


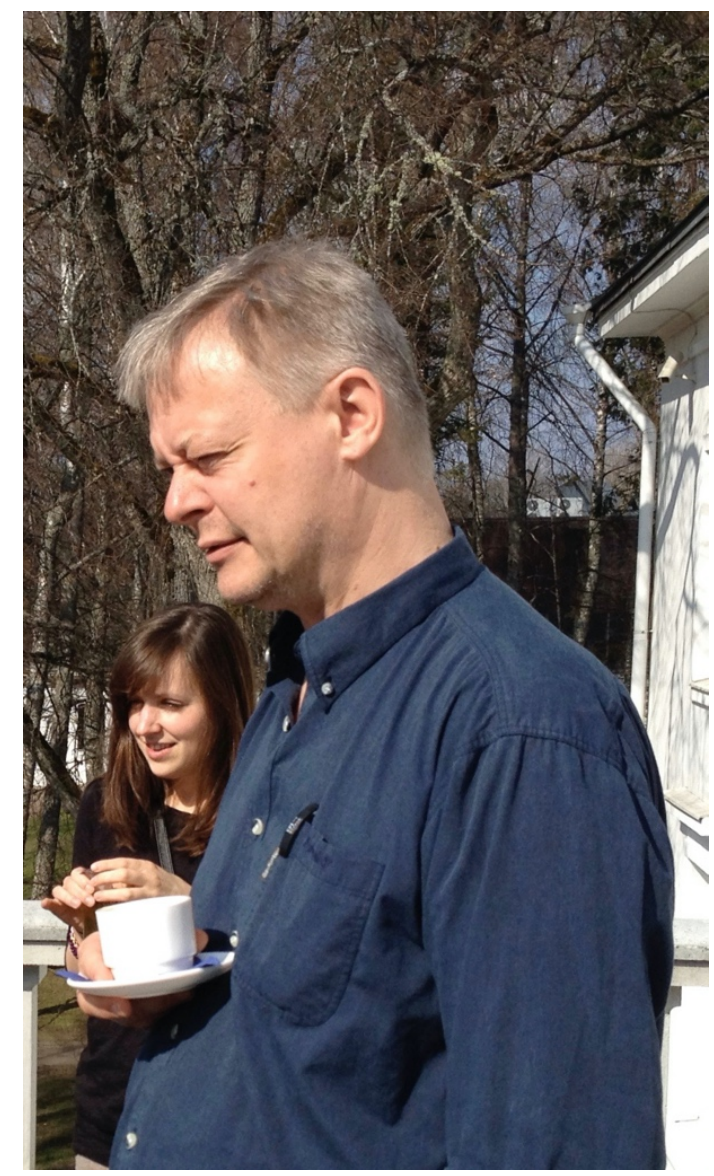

Figure 12. Klavs Hansen. Private photo.

In 2007, Patrik, Jan and I got involved in a Nordic collaboration on atmospheric clusters and aerosols, headed by Hanna Vehkamäki, Helsinki university. The team also included other great scientists; Klavs Hansen (Gothenburg) and Steen Brфndsted Nielsen (Aarhus). I already knew Steen Brøndsted through Steen Hammerum. This collaboration was very successful on my part by providing new opportunities for experiments, extending the scope of my research in several ways. Hanna and her colleagues introduced us to the kinetics of atmospheric aerosol formation and demonstrated how fundamental cluster chemistry in this way is connected to the atmospheric radiation budget and thereby the climate. As a project emerging from the Nordic collaboration, Patrik performed a series of experiments on the stability of water clusters in his characteristic skilful manner and Klavs provided physical insights, helping us to relate the kinetics and thermodynamics of cluster condensation and evaporation. Using Klavs' method, we were able to elegantly extract water binding energies directly from the appearance of the mass spectrum only using the bulk evaporation energy as reference value (Hansen,2009). I still read that paper with great joy. 


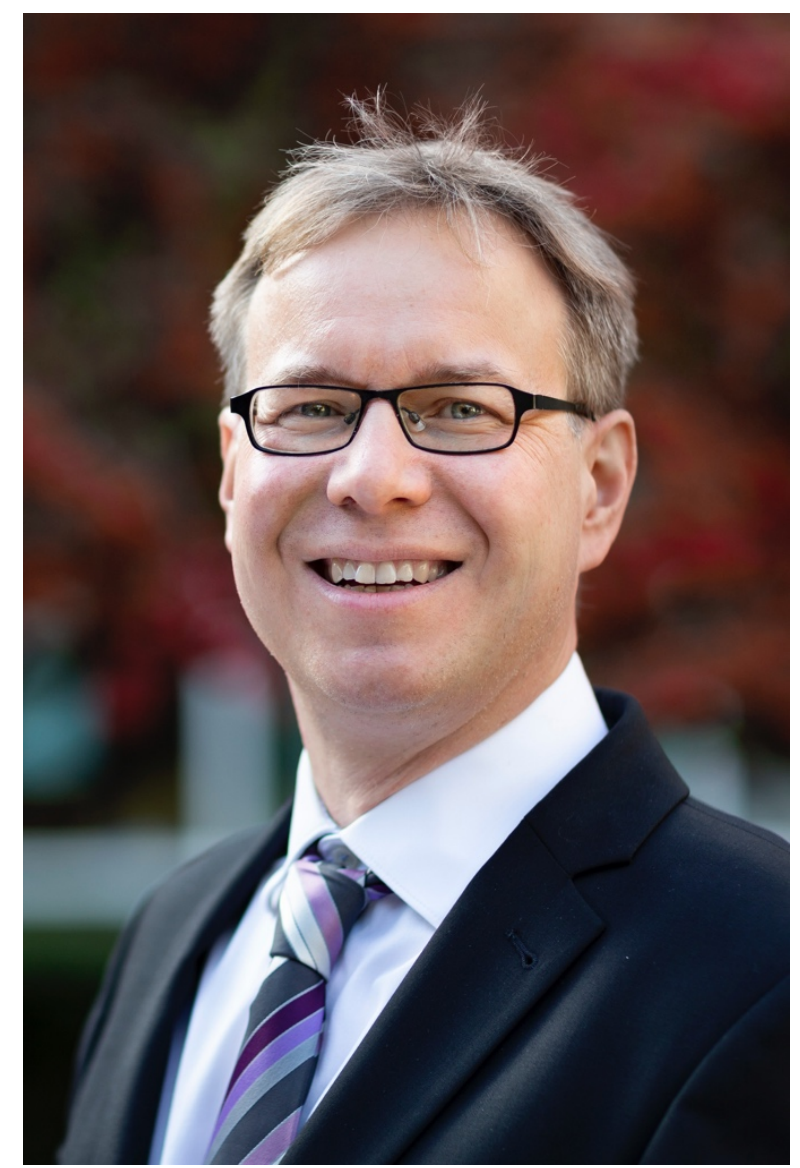

Figure 13. Steen Brøndsted Nielsen. Photo: Melissa Yildrim, Aarhus universitet.

In a continuation of this, Patrik, his student Mauritz Ryding, and I came up with the idea of measuring proton migration in water - a fundamental chemical property - by simply reacting protonated water clusters of variable size with heavy water in the gas phase. In these experiments we noted a variable tendency for $\mathrm{H} / \mathrm{D}$ exchange depending upon cluster size and the lifetime of the of the intermediate $\left[\mathrm{H}_{3} \mathrm{O}^{+}\left(\mathrm{H}_{2} \mathrm{O}\right)_{n} \mathrm{D}_{2} \mathrm{O}\right]$ formed:

$$
\mathrm{H}_{3} \mathrm{O}^{+}\left(\mathrm{H}_{2} \mathrm{O}\right)_{n}+\mathrm{D}_{2} \mathrm{O} \rightarrow\left[\mathrm{H}_{3} \mathrm{O}^{+}\left(\mathrm{H}_{2} \mathrm{O}\right)_{n} \mathrm{D}_{2} \mathrm{O}\right] \rightarrow \text { loss of } \mathrm{H}_{2} \mathrm{O}, \mathrm{HDO} \text { or } \mathrm{D}_{2} \mathrm{O}
$$

On the basis of these conceptually simple but practically challenging experiments we could estimate the rate proton migration within $\left[\mathrm{H}_{3} \mathrm{O}^{+}\left(\mathrm{H}_{2} \mathrm{O}\right)_{n} \mathrm{D}_{2} \mathrm{O}\right]$ and relate this to proton migration in bulk water (Andersson,2008). In stark contrast, essentially no H/D exchange was observed in corresponding experiments with $\mathrm{NH}_{4}+\left(\mathrm{H}_{2} \mathrm{O}\right)_{n}$, for which the proton appears to be immobilized being fixed in the form of a core ammonium ion. These initial experiments gave rise to a series of investigations of water clusters with different core ions. We noted that when there are two basic centres, for example as in $\mathrm{H}^{+}(\text {Pyridine })_{2}\left(\mathrm{H}_{2} \mathrm{O}\right)_{n}$ the proton no longer knows 
to which of the two basic centres it belongs and so becomes mobile, almost as if the pyridines were not there (Ryding,2011). The mechanism was elegantly pinned down when we substituted the two pyridines with bipyridyl molecules having different linkages and relative positions of the two nitrogens (Zatula,2012).

One classical topic in cluster chemistry is the existence of magic numbers. They are particularly stable cluster sizes compared to their neighbours. For water clusters, $\mathrm{H}_{3} \mathrm{O}^{+}\left(\mathrm{H}_{2} \mathrm{O}\right)_{20}$, gives rise to a strongly enhanced signal in the distribution spectrum. By substituting, step-by-step, water molecules in this cluster with $t$-butanol, we were able to probe the structure and concluded that the surface of the cluster has 9 "dangling" hydrogen atoms sticking out of the surface, rather than 10 as it would have in a structure where the twenty waters form a perfect dodecahedral structure with the hydronium trapped inside this cage as in the classical structural interpretation (Ryding,2015). Our conclusion, supported also by quantum chemical calculations, is that the hydronium ion is integrated in the surface and that the network of hydrogen bonded water molecules forms a greatly distorted dodecahedron.

Steen Brøndsted Nielsen is widely known for setting up and conducting very elaborate gas phase spectroscopy and photochemical experiments, but when I visited his lab in Aarhus in 2008, we decided to do something rather simple. He and his colleague Preben Hvelplund had a home-built grand scale mass spectrometer equipped with a corona discharge source where we studied the reduction of water clusters

$$
\mathrm{H}^{+}\left(\mathrm{H}_{2} \mathrm{O}\right)_{n} \rightarrow\left(\mathrm{OH}^{-}\right)\left(\mathrm{H}_{2} \mathrm{O}\right)_{\mathrm{m}} ; n=1-72
$$

by double electron transfer from Cs atoms at $50 \mathrm{keV}$ energies (Panja,2009). On average, more than half of the water molecules plus two hydrogen atoms are lost from the cluster in the process. This was the molecular physics version of the classroom demonstration experiment of throwing metallic caesium on water. We were able to come up with a model where two successive collisions occur within a time period of less than $100 \mathrm{~ns}$, of which the first electron transfer occurs spontaneously at long distance between the collision partners while the second, endothermic, transfer requires substantial collisional energy transfer upon direct impact. 
In the summer of 2011 I was invited as guest professor at Université Pierre et Marie Curie in Paris by Jean-Claude Tabet. Jean-Claude was in all respects an extrordinary host, being full of enthusiasm, humour and knowledge, keeping an exclusive wine cellar (Bordeaux and Châteauneuf-du-Pape), and providing me with the time and talent of three postdocs to help me conduct my little research plan. We worked very efficiently despite the summer heat and were able to characterize a novel structural form of activated carbon dioxide bonded to magnesium and probe its chemical reactivity in the isolated gas phase (Dossmann 2012). It turned out that in this reduced form the $\mathrm{CO}_{2}$ is a carbene, having a nucleophilic carbon atom that is able to form $\mathrm{C}-\mathrm{C}$ bonds in $\mathrm{S}_{\mathrm{N}} 2$ reactions or by adding to the carbonyl group of carbohydrates, bearing some recemblance to the Calvin cycle of photosynthesis. A few years later we teamed up with the distinguished Knut Asmis and his great team at the Fritz-Haberinstitute in Berlin, where we took advantage of their brand new free electron laser. Based on the results from infrared action spectroscopy experiments, we could unequivocally prove that the structure of our magnesium/ $\mathrm{CO}_{2}$ complex indeed was as predicted by our high level quantum chemical calculations (Miller,2014). Since then we have been able to continue and widen the $\mathrm{CO}_{2}$ reduction project in collaboration with three more great colleagues, Knut Børve (Universitetet i Bergen), Sotiris Xantheas (Pacific Norwest National laboratory) and Marc Johnson (Yale university). I should mention that Knut Børve and I have also collaborated on cluster chemistry, already from the days of the Nordic project on atmospheric aerosols. Knut is wise and kind, with a critical no-nonsense attitude to science I appreciate very much. 


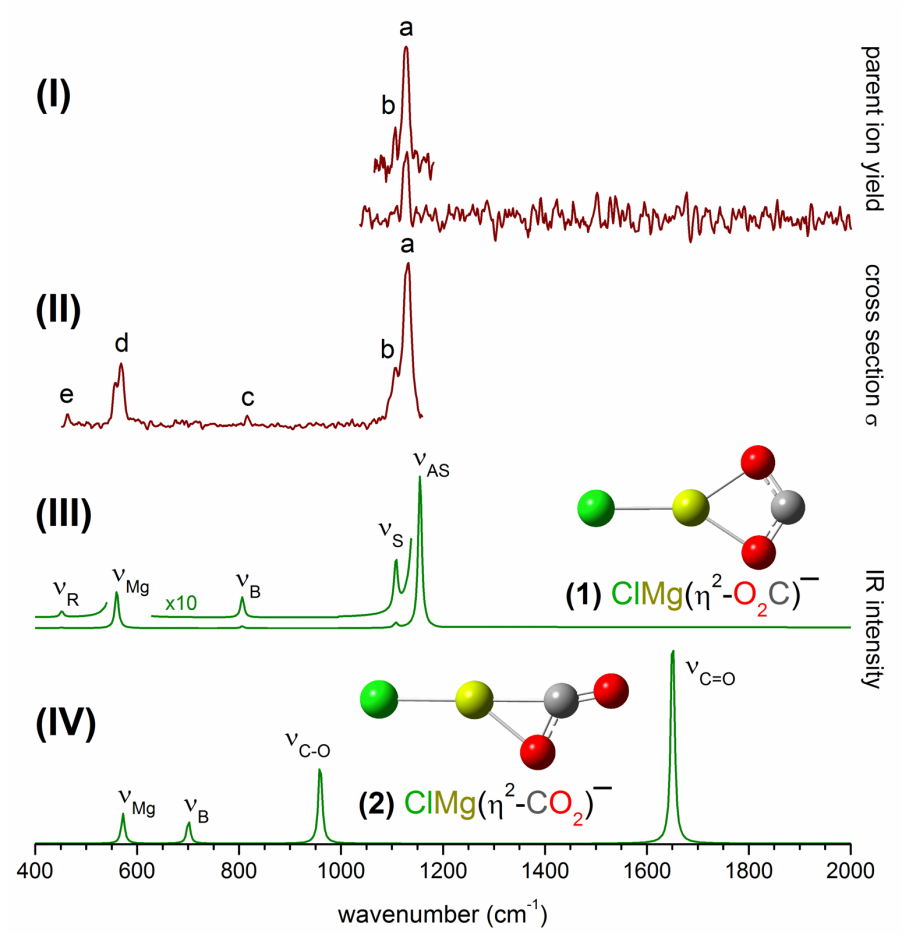

Figure 14. Vibrational predissociation spectra of $\mathrm{ClMgCO}_{2}^{-} \cdot \mathrm{D}_{2}$, measured with a table-top laser system from 1050 to $2000 \mathrm{~cm}^{-1}$ (I) and with a free electron laser from 450 to $1140 \mathrm{~cm}^{-1}$ (II). Simulated IR spectra for $\left[\mathrm{ClMg}\left(\eta^{2}-\mathrm{O}_{2} \mathrm{C}\right)\right]^{-}(\mathbf{I I I})$ and $\left[\mathrm{ClMg}\left(\eta^{2}-\mathrm{CO}_{2}\right)\right]^{-}(\mathbf{I V})$ based on high level ab initio calculations. Reproduced from (Miller,2014) with permission from the copyright holder.

My little story is coming towards its end, but I hope I still will have many years to finish running projects and pursue new ideas. My grandfather, from which I got my name, came from the Solør region in the east of Norway, where I can trace my paternal line back to the late 1500s. In Solør people are unassuming, so I should be careful in stating the impact of my own scientific work. All I can say is that I am very happy with what I have achieved and the work I have been priveledged to contribute to. I hope that is evident from this brief account. Above I have presented papers that I consider to be my best in the sense that I am satisfied with their quality and because I think they are worthy contributions to molecular science. When I now look up these papers in SciFinder or Google, I notice that some have recieved a large number of citations, while some are hardly cited at all. It is very difficult for me to understand this difference and I am unable to find the correlation between quality and the number of citations. This seems also to apply to papers I read from colleagues. So, dear reader, please be critical to citation indeces and impact factors. Almost by definition it is impossible to quantify quality. 
Finally, after 20 years I now step down from my editorship in Mass Spectrometry Reviews, an appointment I was given by Nico Nibbering. He and Dom Desiderio had already spent a lot of time and effort in improving the quality of the journal when I came aboard, and Dom has continued this work through all these years. I am very greatful for Dom's tolerant but firm leadership that has been instrumental for the success of the journal. I am also grateful for the good editorial collegial spirit from Michael Guilhaus, Paul Vorous, Carlito Lebrilla and Richard Cole. I am particularly happy that my baton is now being passed over to Hillka Kenttämaa. Good luck, Hilkka!

I am grateful for this opportunity to write down a sketch about my scientific endevaours and in particular to those who contributed to this special issue, their names are all mentioned above, and to Steen Brøndsted Nielsen for his efforts in putting it together.

\section{References}

Uggerud E, Derrick PJ. 1991. Theory of collisional activation of macromolecules. Impulsive collisions of organic ions. J Phys Chem 95:1430-1436.

Uggerud E, Helgaker T. 1992. Dynamics of the reaction $\mathrm{CH}_{2} \mathrm{OH}^{+} \rightarrow \mathrm{CHO}^{+}+\mathrm{H}_{2}$. Translational energy release from ab initio trajectory calculations. J Am Chem Soc 114:42654268

Uggerud E. 1999. Translational energy release: Experiment and theory. $\mathrm{H}_{2}$ elimination reactions of small gas phase ions, and correspondence to $\mathrm{H}-\mathrm{H}$ bond activation. Mass Spectrom Rev 18:285-308.

Øiestad AML, Uggerud E. 1997. Loss of $\mathrm{H}_{2}$ from $\mathrm{CH}_{2} \mathrm{NH}_{2}{ }^{+}$and $\mathrm{NHNH}_{2}{ }^{+}$. Reaction mechanisms and dynamics from observation of metastable ion fragmentations and ab initio calculations. Int J Mass Spectrom Ion Proc 167-168:117-126.

Hvistendahl G, Uggerud E. 1991. A Combined Theoretical and Experimental Approach to the Unimolecular Loss of Molecular Hydrogen from Protonated Formaldehyde: Determination of the Average Internal Energy of Metastable $\left[\mathrm{CH}_{2} \mathrm{OH}\right]^{+}$Ions. Org Mass Spectrom 26:67-73. 
Lin H-Y, Ridge DP, Uggerud E, Vulpius T. 1994. Unimolecular Chemistry of Protonated Formamide. Mass Spectrometry and ab Initio Quantum Chemical Calculations. J Am Chem Soc 116:2996-3004.

Kinser RD, Ridge DP, Hvistendahl G, Rasmussen B, Uggerud E. 1996. The Unimolecular Chemistry of Protonated Glycinamide and the Proton Affinity of Glycinamide. Mass Spectrometric Experiments and Theoretical Models. Chem Eur J 2:1143.

Bueker H-H, Uggerud E. 1995. Energetics and Dynamics of Intermolecular Proton-Transfer Processes. 1. Ab Initio Studies of the Potential Energy Surface for the Reaction $\mathrm{H}_{3} \mathrm{O}^{+}+\mathrm{NH}_{3}$ $\rightarrow \mathrm{NH}_{4}^{+}+\mathrm{H}_{2} \mathrm{O}$. J Phys Chem 99:5945-5949.

Bueker HH, Helgaker T, Ruud K, Uggerud E. 1996. Energetics and Dynamics of Intermolecular Proton-Transfer Processes. 2. Ab Initio Direct Dynamics Calculations of the Reaction $\mathrm{H}_{3} \mathrm{O}^{+}+\mathrm{NH}_{3} \rightarrow \mathrm{NH}_{4}^{+}+\mathrm{H}_{2} \mathrm{O}$. J Phys Chem 100:15388-15392.

Øiestad ÅML, Petersen AC, Bakken V, Vedde J, Uggerud E. 2001. The Oxidative Power of Protonated Hydrogen Peroxide. Angew Chem Int Ed 40:1305-1309.

Uggerud E, Bache-Andreassen L. 1999. Theoretical Models and Experimental Data for Reactions between Water and Protonated Alcohols: Substitution and Elimination Mechanisms. Chem Eur J 5:1917-1930.

Uggerud E. The Factors Determining Reactivity in Nucleophilic Substitution. In: Williams I, Williams N, eds. Advances in Physical Organic Chemistry. Vol 51. Elsevier; 2017.

Laerdahl JK, Uggerud E. 2003. Nucleophilic identity substitution reactions. The reaction between water and protonated alcohols. Org Biomol Chem 1:2935-2942.

Adlhart C, Uggerud E. 2006. Reactions of platinum clusters $\mathrm{Pt}_{n}{ }^{ \pm}, n=1-21$, with $\mathrm{CH}_{4}$ : to react or not to react. Chem Commun: $2581-2582$. 
Andersson PU, Öjekull J, Pettersson JBC, Markovi'c N, Hellberg F, Thomas RD, Ehlerding A, Österdahl F, Zhaunerchyk V, Geppert WD, af Ugglas M, Larsson M, Uggerud E, Danared H, Källberg A. 2010. Formation of Highly Rovibrationally Excited Ammonia from Dissociative Recombination of $\mathrm{NH}_{4}^{+}$. J Phys Chem Lett 1:2519-2523.

Hansen K, Andersson PU, Uggerud E. 2009. Activation energies for evaporation from protonated and deprotonated water clusters from mass spectra. J Chem Phys 131:124303.

Andersson PU, Ryding MJ, Sekiguchi O, Uggerud E. 2008. Isotope exchange and structural rearrangements in reactions between size-selected ionic water clusters, $\mathrm{H}_{3} \mathrm{O}^{+}\left(\mathrm{H}_{2} \mathrm{O}\right)_{n}$ and $\mathrm{NH}_{4}^{+}\left(\mathrm{H}_{2} \mathrm{O}\right)_{n}$, and $\mathrm{D}_{2} \mathrm{O}$. Phys Chem Chem Phys 10:6127-6134.

Ryding MJ, Zatula AS, Andersson PU, Uggerud E. 2011. Isotope exchange in reactions between $\mathrm{D} 2 \mathrm{O}$ and size-selected ionic water clusters containing pyridine, $\mathrm{H}+($ pyridine $) \mathrm{m}(\mathrm{H} 2 \mathrm{O}) \mathrm{n}$. Phys Chem Chem Phys 13:1356-1367.

Zatula AS, Ryding MJ, Uggerud E. 2012. Concerted proton migration along short hydrogen bonded water bridges in bipyridine-water clusters. Phys Chem Chem Phys 14:13907-13909.

Ryding MJ, Izsak R, Merlot P, Reine S, Helgaker T, Uggerud E. 2015. Geometry of the magic number $\mathrm{H}^{+}\left(\mathrm{H}_{2} \mathrm{O}\right)_{21}$ water cluster by proxy. Phys Chem Chem Phys 17:5466-5473.

Panja S, Hvelplund P, Nielsen SB, Uggerud E. 2009. The reduction of water clusters $\mathrm{H}^{+}\left(\mathrm{H}_{2} \mathrm{O}\right)_{n}$ to $\left(\mathrm{OH}^{-}\right)\left(\mathrm{H}_{2} \mathrm{O}\right)_{m}$ by double electron transfer from Cs atoms. Phys Chem Chem Phys, 11:6125-6131.

Dossmann H, Afonso C, Lesage D, Tabet J-C, Uggerud E. 2012. Formation and Characterization of Gaseous Adducts of Carbon Dioxide to Magnesium, $\left(\mathrm{CO}_{2}\right) \mathrm{MgX}^{-}(\mathrm{X}=\mathrm{OH}$, Cl, Br). Angew Chem Int Ed 51:6938-6941.

Miller GBS, Esser TK, Knorke H, Gewinner S, Schöllkopf W, Heine N, Asmis KR, Uggerud E. 2014. Spectroscopic Identification of a Bidentate Binding Motif in the Anionic Magnesium- $\mathrm{CO}_{2}$ Complex $\left(\left[\mathrm{ClMgCO}_{2}\right]^{-}\right)$. Angew Chem Int Ed 53:14275-14609. 
